\title{
Antioxidant activity and neuroprotective effect of ethyl acetate fraction of Lonicera japonica on $\mathrm{H}_{2} \mathrm{O}_{2}$-induced oxidative stress
}

\author{
Hye Rin Jeong, Jong Min Kim, Jin Yong Kang, Jong Hyun Moon, Min Ji Kim, \\ Hyo Lim Lee, Min Ji Go, Su Yeon Gu, Hyun Jin Kim, Ho Jin Heo* \\ Division of Applied Life Science (BK21), Institute of Agriculture and Life Science, \\ Gyeongsang National University, Jinju 52828, Korea
}

\section{금은화 에틸 아세테이트 분획물의 항산화 활성 및 $\mathrm{H}_{2} \mathrm{O}_{2}$ 로 유도된 산화적 스트레스에 대한 신경세포 보호 효과}

\author{
정혜린 · 김종민 · 강진용 · 문종현 · 김민지 · 이효림 · 고민지 · 구수연 · 김현진 · 허호진* \\ 경상대학교 응용생명과학부(BK21), 농업생명과학연구원
}

\begin{abstract}
Lonicera japonica are commonly used in herbal medicine for the antipyretic, detoxicant and anti-inflammatory actions. In this study, the in vitro antioxidant activity and neuronal protective effects of the ethyl acetate fraction of $L$. japonica (EFLJ) on $\mathrm{H}_{2} \mathrm{O}_{2}$-induced hippocampal $\mathrm{HT22}$ and human neuroblastoma MC-IXC cells were evaluated. The $40 \%$ ethanolic extracts of $L$. japonica showed higher total phenolic and flavonoid contents than those of other ethanolic extracts. EFLJ showed higher 2,2'-azino-bis(3-ethylbenzothiazoline-6-sulfonic acid (ABTS) and 1,1-dphenyl-2-picrlhydrazyl (DPPH) radical scavenging activities than those of other fractions. EFLJ exhibited significant antioxidant activity, as determined by feric reducing/antioxidant power (FRAP) assay, and showed inhibitory effects on malondialdehyde (MDA) production. EFLJ inhibited acetylcholinesterase (AChE) activity. In addition, EFLJ inhibited the production of reactive oxygen species and increased cell viability in $\mathrm{H}_{2} \mathrm{O}_{2}$-induced $\mathrm{HT22}$ and MC-IXC cells, as determined by 3-(4,5-dimethyl-thiazol-2-yl)-2,5-diphenyl tetrazolium bromide (MTT) and 2',7'dichlorofluorescein diacetate (DCF-DA) assays. The main phenolic compounds in EFLJ identified by ultra-high performance liquid chromatography-quadrupole time of flight/mass spectrometry (UPLC-QTOF/MS) were chlorogenic acid, quercetin pentoside, luteolin-7-glucoside, 3,4-dicaffeoylquinic acid, 1,3-dicaffeoylquinic acid and 1,4dicaffeoylquinic acid. These results suggested that EFLJ includes various compounds with considerable antioxidant activity and neuronal protective effects against oxidative stress-induced cellular cytotoxicity. Therefore, EFLJ is a valuable functional food material for the prevention and improvement of neurodegenerative disorders.
\end{abstract}

Keywords : Lonicera japonica, antioxidant activity, neuroprotective effect, hippocampal HT22 cells, neuroblastoma MC-IXC cells

\section{서 론}

현대사회에서 과학기술의 발달, 경제 수준의 향상으로 인
해 인간 평균 수명의 연장과 국민 건강에 대한 관심은 증가된 반면, 음주, 흡연, 신체 활동들의 감소, 스트레스 등의 건강 위험 요인은 증가하고 있다(Lee 등, 2017). 이러한 요인들은

*Corresponding author. E-mail : hjher@gnu.ac.kr, Phone : +82-55-772-1907, Fax : +82-55-772-1909

Received 19 July 2021; Revised 09 September 2021; Accepted 09 September 2021.

Copyright (c) The Korean Society of Food Preservation.

This is an Open Access article distributed under the terms of the Creative Commons Attribution Non-Commercial License (http://creativecommons.org/licenses/by-nc/4.0) which permits unrestricted non-commercial use, distribution, and reproduction in any medium, provided the original work is properly cited. 
인체의 노화나 여러 가지 합병증을 유발하며, 그 주요 원인인 활성산소종(reactive oxygen species, ROS)은 세포의 미토콘 드리아에서 산소를 사용하여 에너지를 생성할 때, 산화 환원 과정에서 발생하는 부산물이다(Pham-Huy 등, 2008). 이는 세포 산화 환원 신호 및 면역 기능에 유익한 효과를 나타내지 만, 그 함량이 높아질 경우, 세포 기능과 구조를 손상시킬 수 있는 유해한 산화적 스트레스로 작용한다고 알려져 있다 (Sen 등, 2010). ROS는 superoxide radical, hydroxyl radical, singlet oxygen 및 $\mathrm{H}_{2} \mathrm{O}_{2}$ 등의 산화적 스트레스를 생성하여 세포막 분해, 단백질 분해, 지방 산화, DNA 합성 억제 등 생 체 내 심각한 생리적 장애를 발생시킨다(Behl와 Moosmann, 2002).

뇌 조직은 높은 산소 소비량과 고농도의 불포화 지방산으 로 구성되어 있는데, 이는 다른 조직에 비해서 상대적으로 낮 은 항산화 방어 기전을 가지며, 산화적 스트레스에 민감하게 반응하는 조직이다(Choi 등, 2012). 체내 활성산소종이 과도 하게 생성될 경우, 뇌의 DNA, 막 지질, 막 단백질과 같은 거 대 분자와 반응을 하며, 이는 결과적으로 세포막의 지질 과산 화를 일으키는 연쇄반응으로 이어져 거대 분자에 매우 파괴 적으로 작용하여 주요 뇌 신경세포의 손상을 일으킨다(Niki 등, 1993). 이러한 산화적 스트레스는 뇌의 기능적 효율성의 저하, 느려진 반응, 기억력 감소, 떨림 및 신경 기능의 문제를 일으키며, 이는 세포자살(apoptosis) 및 세포괴사(necrosis)를 유도하여 궁극적으로 $\mathrm{AD}$ 및 뇌졸증을 포함한 신경 퇴행성 질환 등을 일으키는 것으로 알려져 있다(Lim과 Kim, 2007; Reiter, 1995). 이러한 퇴행성 질환을 개선하기 위해 다각도 로 연구되고 있으나, 뇌조직의 경우 손상이 되면 기능의 회복 이 어렵고, 현재 개발된 합성 의약품은 그 효능 여부와 부작 용 등의 논란이 크게 대두되고 있다. 따라서 뇌조직에서의 산 화적 스트레스의 균형 대사를 위해서는 천연 항산화제의 적 절한 섭취가 중요하다.

이러한 산화적 스트레스를 억제시키는 항산화제는 합성 항산화제인 butylated hydroxyanisole(BHA), butylated hydroxytoluene(BHT)이 경제성과 높은 항산화력으로 인해 널 리 사용됐지만, 합성 항산화제의 경우, 다양한 부작용 등 안 전성에 논란이 있어, 허용 대상 식품이나 사용량이 엄격히 규 제되고 있다(Yoon 등, 2013). 따라서, 안전하게 오랫동안 섭 취된 천연물로부터 인체에 안전하고 항산화력이 높은 물질을 이용하는 연구가 활발히 진행되고 있다(Cho 등, 2008). 이에 따라, 항산화 효과와 안정성을 확보한 뇌 신경세포에 대한 산 화적 스트레스를 감소시켜줄 수 있는 천연 항산화제의 섭취 필요성이 대두되고 있다.

금은화(Lonicera japonica)는 동아시아 재래종으로, 인동 과(Caprifoliaceae)에 속하는 인동덩굴(L. japonica)의 꽃봉오 리 또는 막 피기 시작한 꽃으로 주로 여름철 꽃이 피기 전에
채취된다(Shin 등, 2012). 금은화는 항균 효과, 미백효과 등 이 보고되고 있으며, 그 외에 간 손상, 호흡기 관련, 망막허혈 및 혈소판 활성 등의 개선 효과 등에 이르기까지 다양한 분야 에 걸쳐 연구가 진행되고 있다(Bae 등, 2005; Kim 등, 2011; $\mathrm{Yu}$ 등, 2017). 다양한 연구가 수행되었음에도 뇌 신경세포 보호 효과와 관련한 생리활성 연구는 미흡한 실정이다. 따라 서 본 연구에서는 금은화의 ethyl acetate 분획물을 활용하여 항산화 활성 평가와 아세틸콜린 분해 억제효과, 과산화수소 로부터 유도된 뇌 신경세포 사멸에 대한 보호 효과를 등을 확인하여, 신경세포의 사멸에 의해 발생되는 퇴행성 뇌질환 의 예방 및 개선를 위한 기능성 식품 소재로서의 활용 가능성 을 평가하고자 연구를 수행하였다.

\section{재료 및 방법}

\section{시료추출 및 분획}

본 실험에 사용한 금은화는 2019년 강원도 양양군의 농가 에서 재배된 것을 구입하여 사용하였다. 시료는 동결건조기 (FDU-8612, Operon, Gimpo, Korea)를 이용하여 건조한 후, 시료 $20 \mathrm{~g}$ 에 $40 \%$ 에탄올 $1 \mathrm{~L}$ 를 첨가하여 2 시간 동안 환류 냉각 추출하였으며, 추출액은 No. 2 여과지(Whatman Inc, Kent, UK)로 여과하여 농축(N-N series, Eyela Co., Tokyo, Japan)하였다. 농축한 추출물은 증류수 $250 \mathrm{~mL}$ 로 정용하고, 같은 양의 $n$-hexane을 분획을 진행하였다. 이 과정과 동일하 게 chloroform 및 ethyl acetate을 이용하여 순차적으로 분획 을 진행하여 분획물을 얻었으며, 이를 동결건조하여 $-20^{\circ} \mathrm{C}$ 에 냉동 보관한 후 각 실험에 사용하였다.

\section{시약}

본 실험에 사용된 시약은 Folin \& Ciocalteu's phenol reagent, $\mathrm{Na}_{2} \mathrm{CO}_{3}$, gallic acid, $\mathrm{NaOH}$, diethylene glycol, rutin, sodium phosphate buffer, 2,2'-azino-bis(3-ethyl benzothiazoline6-sulfonic acid)(ABTS), potassium persulfate, 1,1-diphenyl2-picrylhydrazyl(DPPH), sodium acetate buffer, $\mathrm{HCl}, 2,4,6$-tri (2-pyridyl)-1,3,5-triazine(TPTZ), trichloroacetic acid, thiobarbituric acid, ascorbic acid, cetechin, tris $\mathrm{HCl}$ buffer, 5,5'-dithiobis2-nitrobenzoic acid(DTNB), acetylthiocholine, fetal bovine serum, calf serum, penicillin, streptomycin, $\mathrm{H}_{2} \mathrm{O}_{2}$, Roswell memorial institute medium(RPMI) broth, 2',7'- dichlorofluorescein diacetate(DCF-DA), 3-(4,5-dimethyl-thiazol- 2-yl)-2,5-diphenyl tetrazolium bromide(MTT), Minimum Essential Medium (MEM), Dulbecco Modified Eagle Medium(DMEM), dimethyl sulfoxide(DMSO)는 Sigma-Aldrich Chemical Co. (St. Louis, MO, USA)에서 구입하였고, 그 외 사용된 용매 및 시약은 모두 1 급 이상의 등급을 사용하였다. 


\section{총페놀성 화합물 및 총플라보노이드 함량 측정}

추출한 시료 용액 $1 \mathrm{~mL}$ 와 3차 증류수 $9 \mathrm{~mL}$ 를 혼합한 후, Folin \& Ciocalteu's phenol reagent $1 \mathrm{~mL}$ 를 넣고 혼합하여 5 분간 실온에서 반응시켰다. 혼합용액에 $7 \% \mathrm{Na}_{2} \mathrm{CO}_{3} 10 \mathrm{~mL}$ 를 넣어 다시 혼합하여 3차 증류수로 $25 \mathrm{~mL}$ 를 정용한 뒤, $23^{\circ} \mathrm{C}$ 에서 2시간 동안 반응시킨 후 $760 \mathrm{~nm}$ 에서 흡광도(UV1800 , Shimadzu, Tokyo, Japan)를 측정하였다. 측정된 흡광 도 값은 gallic acid를 이용하여 시료와 동일한 방법으로 수행 된 표준곡선을 통해 총페놀성 화합물 함량을 계산하였다.

총플라보노이드 함량 측정은 시료 용액 $1 \mathrm{~mL}$ 에 diethylene glycol $10 \mathrm{~mL}$ 와 $\mathrm{NaOH} 1 \mathrm{~mL}$ 를 넣고 혼합하여 $30^{\circ} \mathrm{C}$ 에서 1 시 간 동안 반응시킨 후 $420 \mathrm{~nm}$ 에서 흡광도(UV-1800, Shimadzu, Tokyo, Japan)를 측정하였다. 측정된 흡광도 값(optical density, $\mathrm{OD})$ 은 rutin을 사용하여 시료와 동일한 방법으로 작성된 표 준곡선에 대입하여 총플라보노이드 함량을 계산하였다. 우수 한 활성을 가지는 에탄올 추출 농도를 확인하기 위해 0,20 , $40,60,80$ 및 $95 \%$ 에탄올 추출물을 이용하여 실험을 진행하 였다.

\section{$\mathrm{ABTS}$ 및 DPPH 라디칼 소거활성}

$\mathrm{ABTS}$ 라디칼 소거 활성 측정은 $150 \mathrm{mM} \mathrm{NaCl}$ 이 포함된 $100 \mathrm{mM}$ sodium phosphate buffer(pH 7.4)에 $1.0 \mathrm{mM} \mathrm{2,2'-}$ azobis-(2-amidinopropane) $\mathrm{HCl}(\mathrm{AAPH})$ 과 $2.5 \mathrm{mM}$ ABTS를 혼합하여, $68^{\circ} \mathrm{C}$ 항온수조에서 30 분 동안 가열하여 반응시켜 준 후 실온에 10 분 동안 냉각하였다. 만들어진 혼합용액을 Syringe filter로 여과하여 $4^{\circ} \mathrm{C}$ 에서 24 시간 동안 보관 후 사용 하였으며, 흡광도 값이 $734 \mathrm{~nm}$ 에서 $0.70 \pm 0.02$ 가 되게 희석 하였다. 시료 용액 $20 \mu \mathrm{L}$ 에 흡광도 값을 맞춘 $\mathrm{ABTS}$ 용액 $980 \mu \mathrm{L}$ 를 가하여 $37^{\circ} \mathrm{C}$ 에서 10 분간 반응시킨 후 $734 \mathrm{~nm}$ 에서 흡광도(UV-1800, Shimadzu, Tokyo, Japan)를 측정하였다 (Kim 등, 2003).

$\mathrm{DPPH}$ 라디칼 소거활성 측정은 $80 \%$ 메탄올에 $0.1 \mathrm{mM}$ $\mathrm{DPPH}$ 를 용해하여 $517 \mathrm{~nm}$ 에서 흡광도 값이 $1.00 \pm 0.02$ 가 되 도록 희석하였다. 시료 용액 $50 \mu \mathrm{L}$ 에 흡광도 값을 맞춘 $\mathrm{DPPH}$ 용액 $1.45 \mathrm{~mL}$ 를 가하여 30 분간 암실에서 반응시킨 후 $517 \mathrm{~nm}$ 에서 흡광도(UV-1800, Shimadzu, Tokyo, Japan)를 측정하였다(Blois, 1958).

$\mathrm{ABTS}$ 및 DPPH 라디칼 소거활성 측정은 다음 식에 의하 여 계산되었다.

$\mathrm{ABTS}$ 라디칼소거능 $(\%)=$

Blank OD - Sample OD Blank OD 100
$\mathrm{DPPH}$ 라디칼소거능 $(\%)=$

$\frac{\text { Blank OD - Sample OD }}{\text { Blank OD }} \times 100$

\section{철 환원력 측정}

Ferric reducing/antioxidant power(FRAP) 용액 제조 방법 은 $300 \mathrm{mM}$ sodium acetate buffer( $\mathrm{pH}$ 3.6)와 $40 \mathrm{mM} \mathrm{HCl}$ 이 포함된 $10 \mathrm{mM} \mathrm{TPTZ}$ 혼합용액과 $20 \mathrm{mM} \mathrm{FeCl}$ 을 일정한 비율로 배합하여 $37^{\circ} \mathrm{C}$ 에서 15 분간 반응시켜 만들었다. 시료 $50 \mu \mathrm{L}$ 에 만들어진 FRAP 혼합용액 $1.5 \mathrm{~mL}$ 를 가하여 실온에 서 30 분간 반응시킨 다음 $593 \mathrm{~nm}$ 에서 흡광도(UV-1800, Shimadzu, Tokyo, Japan)를 측정하였다(Benzie과 Strain, 1996).

\section{지질과산화물 생성억제활성 측정}

마우스 뇌 조직을 이용한 지질과산화물 생성억제활성을 측정하기 위해 1 주간 사육한 4 주령의 수컷 Institute of Cancer Research(ICR) 마우스를 실험동물공급업체(Samtako, Osan, Korea)로부터 구입하여 항온 $\left(22 \pm 2^{\circ} \mathrm{C}\right)$, 항습(50-55\%) 을 유지하며, 12 시간 간격으로 낮과 밤을 교대시키는 동일한 환경에서 충분한 식수와 사료를 공급하여 사육하였다. 상기 환경에서 사육한 ICR 마우스의 뇌를 적출하여 뇌 조직무게 에 $20 \mathrm{mM}$ tris $\mathrm{HCl}$ buffer(pH 7.4)을 10배 첨가하여 균질화 시켜 원심분리 $\left(12,000 \times g, 15\right.$ 분, $\left.4^{\circ} \mathrm{C}\right)$ 하여 얻어진 상층액을 시험에 사용하였다. 뇌 조직 상층액 $0.1 \mathrm{~mL}, 10 \mu \mathrm{M}$ 황산철 (II) $0.1 \mathrm{~mL}, 0.1 \mathrm{mM}$ 아스코브르산 $0.1 \mathrm{~mL}$ 및 시료 $0.2 \mathrm{~mL}$ 를 혼합하여 $37^{\circ} \mathrm{C}$ 에서 1 시간 동안 반응시켰다. 이후 반응용액 에 $30 \%$ trichloroacetic acid $0.1 \mathrm{~mL}$ 와 $1 \%$ thiobarbituric acid $0.3 \mathrm{~mL}$ 를 첨가하여 $80^{\circ} \mathrm{C}$ 항온수조에서 20 분 동안 가열한 후, 원심분리를 이용하여 얻은 상등액을 $532 \mathrm{~nm}$ 에서 흡광도 (UV-1800, Shimadzu)를 측정하였다(Chang 등, 2001). 본 동 물실험은 경상대학교 동물윤리심의위원회 승인을 거쳐 진행 하였다(경상국립대학교 동물실험 인가번호: GNU-120831M0067).

\section{아세틸콜린 분해효소 억제활성 측정}

아세틸콜린 분해효소(acetylcholinesterase, $\mathrm{AChE}$ ) 억제활 성 측정은 acetylcholine iodide을 기질로 사용하여 측정하였 다. 아세틸콜린 분해효소는 신경세포의 특성을 갖는 $\mathrm{PC} 12$ 세 포 배양액을 $200 \times g$ 에서 6 분간 $4^{\circ} \mathrm{C}$ 에서 원심분리하여 상층 액을 제거하고, 균질화 완충용액 $\left(1 \mathrm{M} \mathrm{NaCl}, 50 \mathrm{mM} \mathrm{MgCl}_{2}\right.$, $1 \%$ Triton X-100(pH 7.2)) $1 \mathrm{~mL}$ 를 넣어 균질화시킨 후, 다 시 원심분리 $\left(12,000 \times g, 30\right.$ 분, $\left.4^{\circ} \mathrm{C}\right)$ 하여 얻어진 상층액을 실 험에 사용했다. $50 \mathrm{mM}$ sodium phosphate buffer( $\mathrm{pH} 8.0)$, 시 료용액 $10 \mu \mathrm{L}$ 및 acetylcholinesterase $10 \mu \mathrm{L}$ 를 혼합하여 $37^{\circ} \mathrm{C}$ 
에서 15 분 동안 방치시킨 후, $50 \mathrm{mM}$ sodium phosphate buffer(pH 8.0)에 용해시킨 $0.5 \mathrm{mM}$ Ellman's 반응용액 $(0.5$ $\mathrm{mM}$ acetylcholine iodide, $1 \mathrm{mM}$ DTNB)을 $70 \mu \mathrm{L}$ 를 첨가하여 $37^{\circ} \mathrm{C}$ 에서 10 분 동안 배양한 후, 흡광도는 microplate reader (Epoch 2, BioTek Instruments Inc., Winooski, VT, USA)로 $405 \mathrm{~nm}$ 에서 측정하였다(Ellman 등, 1961).

\section{뇌 신경세포 배양}

본 실험에 사용한 MC-IXC 세포(CRL-2270, ATCC, Manassas, VA, USA)는 인간의 뇌 조직에서 유래되었으며, 신경세포의 특성을 나타낸다. $\mathrm{MC}-\mathrm{IXC}$ 세포는 $10 \% \mathrm{FBS}$ 와 50 units $/ \mathrm{mL}$ 페니실린 및 $100 \mu \mathrm{g} / \mathrm{mL}$ 스트렙토마이신이 포함 된 $\mathrm{MEM}$ 배지에 접종하여 배양했으며, $37^{\circ} \mathrm{C}$ 에서 $5 \% \mathrm{CO}_{2}$ 조 건에서 배양하였다. Mouse의 뇌 해마 조직에서 유래된 HT22 세포는 경상국립대학교 수의과대학 조직학 실험실에서 2017 년 10 월에 분양받아 사용하였다. HT22 세포는 $10 \%$ calf serum, 50 units $/ \mathrm{mL}$ penicillin 및 $100 \mu \mathrm{g} / \mathrm{mL}$ streptomycin이 포함된 $\mathrm{DMEM}$ 배지에서 $37^{\circ} \mathrm{C}, 5 \% \mathrm{CO}_{2}$ 조건으로 배양했다.

\section{뇌 신경세포 생존율 및 산화적 스트레스 생성억제효과 측정}

뇌 신경세포 생존율은 신경세포 생존력 및 세포독성을 측 정할 수 있는 MTT 실험을 통해 확인할 수 있다. 96 well plate 에 MC-IXC와 HT22 세포를 각 well에 $1.0 \times 10^{4}$ cells/well의 농도로 분주하고 24 시간 배양시킨 후, 시료 용액을 각각의 뇌 신경세포에 처리했다. 24시간 후, $200 \mu \mathrm{M}$ 과산화수소를 처 리하여 3시간 동안 배양기에서 반응을 시켰다. 이후 MTT 용 액을 처리하여 배양기 $\left(37^{\circ} \mathrm{C}, 5 \% \mathrm{CO}_{2}\right)$ 에서 3 시간 동안 배양한 후, 배양액을 제거한 뒤 $\mathrm{DMSO}$ 를 이용하여 반응을 종결시켰 다. 흡광도는 microplate reader(Epoch 2, BioTek Instruments Inc., Winooski, VT, USA) determination wave $570 \mathrm{~nm}$ 와 reference wave $690 \mathrm{~nm}$ 에서 흡광도를 측정하였다(Heo 등, 2001).

산화적 스트레스 생성 억제효과는 뇌 신경세포 내에 활성 산소종의 활성을 측정하는 2',7'-dichlorofluorescein diacetate (DCF-DA) assay을 통해 확인한다. Blank 96 well plate에 $\mathrm{MC}-\mathrm{IXC}$ 와 HT22 세포를 각 well에 $1.0 \times 10^{4}$ cells/well의 농 도로 분주하고, 배양기 $\left(37^{\circ} \mathrm{C}, 5 \% \mathrm{CO}_{2}\right)$ 에 24 시간 동안 배양 시켰으며, 이후 24 시간 동안 배양시킨 후, $200 \mu \mathrm{M}$ 과산화수 소를 처리하여 3 시간 동안 $37^{\circ} \mathrm{C}$ 에서 $5 \% \mathrm{CO}_{2}$ 의 조건으로 반 응을 시켰다. 이후 빛을 차단한 상태에서 $50 \mu \mathrm{M}$ DCF-DA를 처리하여 50 분 동안 배양하였고, 형광광도계(fluorometer, Infinite F200, Tecan, Mannedorf, Swiss)를 사용하여 excitation wave $485 \mathrm{~nm}$ 와 emission wave $535 \mathrm{~nm}$ 에서 형광을 측정하 였다(Heo 등, 2001).

\section{생리활성물질 분석}

금은화의 생리활성 물질을 동정하기 위해 금은화 $40 \%$ 에 탄올 추출물을 ethyl acetate로 분획하여 얻은 동결건조물을 $50 \%$ 메탄올로 녹여 $100 \mu \mathrm{g} / \mathrm{mL}$ 로 샘플을 제작했다. $\mathrm{BEH}$ $\mathrm{C}_{18}$ column $(100 \times 2.1 \mathrm{~mm}, 1.7 \mu \mathrm{m}$; Waters, Milford, MA, USA)이 장착된 ultra performance liquid chromatographyquadrupole-time of flight mass spectrometry(UPLC-QTOF/MS, Xevo G2-S, Waters, Milford, MA, USA)를 이용 하여 분석을 진행하였다. 대사물질의 $\mathrm{MS}^{\mathrm{E}}$ 스펙트럼은 $10-40$ $\mathrm{eV}, 50-1500 \mathrm{~m} / \mathrm{z}$ 에서 분석하였다.

\section{통계처리}

실험 데이터는 반복 실험을 통하여 나타낸 값을 SAS software(version 9.4, SAS institute, Cary, NC, USA)를 이용 한 분산분석(analysis of variance, ANOVA)을 통해 통계처리 를 하였으며, Duncan의 다중범위 검정법(Duncan's multiple range test)으로 $5 \%$ 수준 $(\mathrm{p}<0.05)$ 내에서 각 시료 간의 유의 성을 검증하였다.

\section{결과 및 고찰}

\section{총페놀성 화합물 및 총플라보노이드 함량}

페놀성 화합물은 식물계에 널리 분포된 2차 대사산물로, 페놀성 화합물은 수산기에 의한 수소 공여와 페놀 고리 구조 hydroxyl(-OH)기와 벤젠 고리를 가지고 있는 것이 특징이다. 의 공명 안정화에 의한 항산화 능력을 나타내는 것으로 보고 되고 있다(Kim 등, 2008). 0, 20, 40, 60, 80 및 95\% 에탄올 추출물의 수율은 각각 $26.74 \%, 35.08 \%, 35.36 \%, 32.00 \%$, $30.88 \%, 12.31 \%$ 를 나타냈다(Data not shown). 가장 높은 총 페놀성 화합물의 함량을 가진 추출물은 $40 \%$ 에탄올 추출물 로써, $74.32 \mathrm{mg} \mathrm{GAE} / \mathrm{g}$ 의 함량을 나타냈으며, $60 \%, 80 \%$, $20 \%$ 에탄올 추출물이 각각 $71.86,63.70,63.53 \mathrm{mg} \mathrm{GAE} / \mathrm{g}$ 의 순으로 나타났다(Table 1). 플라보노이드는 폴리페놀에 속 하는 성분으로, 식물의 잎, 꽃, 줄기 및 열매 등에 많이 함유 되어 있으며, 이는 주로 flavonols, flavones 및 flavanones 등 으로 구성되어 있다(Herrmann, 1988; Herto 등, 1993). 금은 화의 총플라보노이드 함량은 $40 \%$ 와 $60 \%$ 에탄올 추출물에서 각각 $53.32,57.86 \mathrm{mg} \mathrm{RE} / \mathrm{g}$ 으로 높은 함량을 보였으며, $80 \%$ 와 $20 \%$ 추출물에서 각각 $52.47,43.24 \mathrm{mg} \mathrm{RE} / \mathrm{g}$ 으로 나타났 다(Table 1).

Song 등(2018)의 연구에 따르면 다양한 방법(진탕, 열수, 초음파, 침지)으로 추출하여 용매별 폴리페놀 함량과 금은화 의 chlorogenic acid의 추출 효율을 측정한 결과, 열수 추출과 $40 \%, 60 \%, 80 \%$ 에탄올 농도일 때 상대적으로 폴리페놀 함 
Table. 1. Total phenol contents (TPC) and total flavonoid contents (TFC) of ethanolic extract of Lonicera japonica

\begin{tabular}{ccccccc}
\hline & \multicolumn{5}{c}{ Ethanolic extract (\%) } \\
\cline { 2 - 7 } & $0 \%$ & $20 \%$ & $40 \%$ & $60 \%$ & $80 \%$ & $95 \%$ \\
\hline $\mathrm{TPC}^{1)}$ & $60.63 \pm 0.79^{\mathrm{d}}$ & $63.53 \pm 0.70^{\mathrm{c}}$ & $74.32 \pm 0.91^{\mathrm{a}}$ & $71.86 \pm 2.36^{\mathrm{b}}$ & $63.70 \pm 0.40^{\mathrm{c}}$ & $40.37 \pm 1.21^{\mathrm{e}}$ \\
$\mathrm{TFC}^{2)}$ & $34.65 \pm 0.38^{\mathrm{d}}$ & $43.24 \pm 1.60^{\mathrm{c}}$ & $56.32 \pm 2.25^{\mathrm{a}}$ & $57.86 \pm 0.97^{\mathrm{a}}$ & $52.47 \pm 1.78^{\mathrm{b}}$ & $25.29 \pm 2.35^{\mathrm{e}}$ \\
\hline
\end{tabular}

${ }^{1)} \mathrm{TPC}$, total phenolic contents.

${ }^{2)}$ TFC, total flavonoid contents.

Results of TPC and TFC are presented as $\mathrm{mg} \mathrm{GAE} / \mathrm{g}$ and $\mathrm{mg} \mathrm{RE} / \mathrm{g}$, respectively. Values are mean $\pm \mathrm{SD}$ ( $\mathrm{n}=3$ ). Different small letters represent significant differences at $\mathrm{p}<0.05$.

량 및 chlorogenic acid의 추출 효율이 높은 것으로 보아, 이 는 유효 성분의 효율적인 추출조건으로 판단된다. Shin과 Yoo(2012)의 연구에 따르면 총페놀성 화합물 분석 결과, 금 은화 $70 \%$ 에탄올 추출물이 열수 추출물보다 높은 페놀성 화 합물과 총플라보노이드 함량이 높게 나타났음을 제시하였고, 이는 $70 \%$ 에탄올 추출물이 금은화 주요 성분인 chlorogenic acid, hesperidine, naringine, luteolin 등과 같은 polyphenol 류 생리 활성 성분을 더 효과적으로 추출하기 때문으로 판단 된다. 본 연구에서는 금은화의 $0,20,40,60,80$ 및 $95 \%$ 로 농도를 에탄올 추출물들의 총페놀성 화합물 함량과 총플라보 노이드 함량을 비교했을 때, 40 과 $60 \%$ 에서 높은 총페놀성 화 합물 및 총플라보노이드 함량을 확인함으로써 항산화 물질이 다량 함유되어 있다는 것을 알 수 있었다. 이에 따라 총페놀 성 화합물 함량과 총플라보노이드 함량이 가장 높게 나타난 $40 \%$ 에탄올 추출물을 사용하여 분획을 진행하였으며, $n$ hexane, chloroform, ethyl acetate 및 증류수 분획물을 각각 얻었다.

\section{생리활성물질 분석}

항산화 및 뇌 신경세포 보호 효과를 보여주는 금은화 ethyl acetate 분획물의 생리활성 물질을 동정하기 위해, UPLC$\mathrm{Q}-\mathrm{TOF} / \mathrm{MS}^{\mathrm{E}}$ 를 이용하여 주요 생리활성 물질에 관한 분석연
구를 진행했으며, 구성 화합물의 fragmentation 및 retention time을 이용하여 각각 확인했다(Fig. 1과 Table 2). 금은화 ethyl acetate 분획물에서 분리된 화합물은 크로마토그램으로 나타냈으며, 동정된 생리활성 물질은 chlorogenic acid(4.53 $\mathrm{min}$ ), quercetin pentoside(5.06 min), luteolin-7-glucoside(5.12 $\mathrm{min}$ ), 3,4-dicaffeoylquinic acid(5.21 min), 1,3-dicaffeoylquinic $\operatorname{acid}(5.28 \mathrm{~min}), 1$,4-dicaffeoylquinic $\operatorname{acid}(5.36 \mathrm{~min})$ 로 확인 하였다(Clifford 등, 2005; Goger 등, 2019; Hvattum, 2002). Kwon 등(2010)에 따르면, scopolamine으로 유도된 기억력이 손상된 동물 모델에서 chlorogenic acid의 섭취는 Y-maze 실 험과 Morris water maze 실험을 통해 단기기억 능력 및 작업 기억의 손상을 유의적으로 개선했다. 또한, 해마와 전두엽 피 질에서 $\mathrm{AChE}$ 와 $\mathrm{MDA}$ 억제를 통해서 세포 보호 효과를 나타냈 다. Lima 등(2006)에 따르면, 간암 세포종인 HepG2 세포에서 tert-butyl hydroperoxide(t-BHP)로 유도된 세포 사멸에 대한 luteolin-7-glucoside의 세포 보호 효과를 확인해 본 결과, 지 질과산화의 부산물인 thiobarbituric acid reactive substances (TBARS)의 수준을 감소시켰으며, t-BHP에 의한 GSH 수준 감소에 대해 우수한 보호 효과를 보였다. Kim 등(2005)에 따 르면, 인간 신경 모세포종인 SH-SY5Y 세포에서 과산화수소 로 유도된 신경세포 사멸에 대한 보호 효과를 연구한 결과, 3,4-di-O-caffeoylquinic acid(3,4-diCQA)에 의한 신경세포

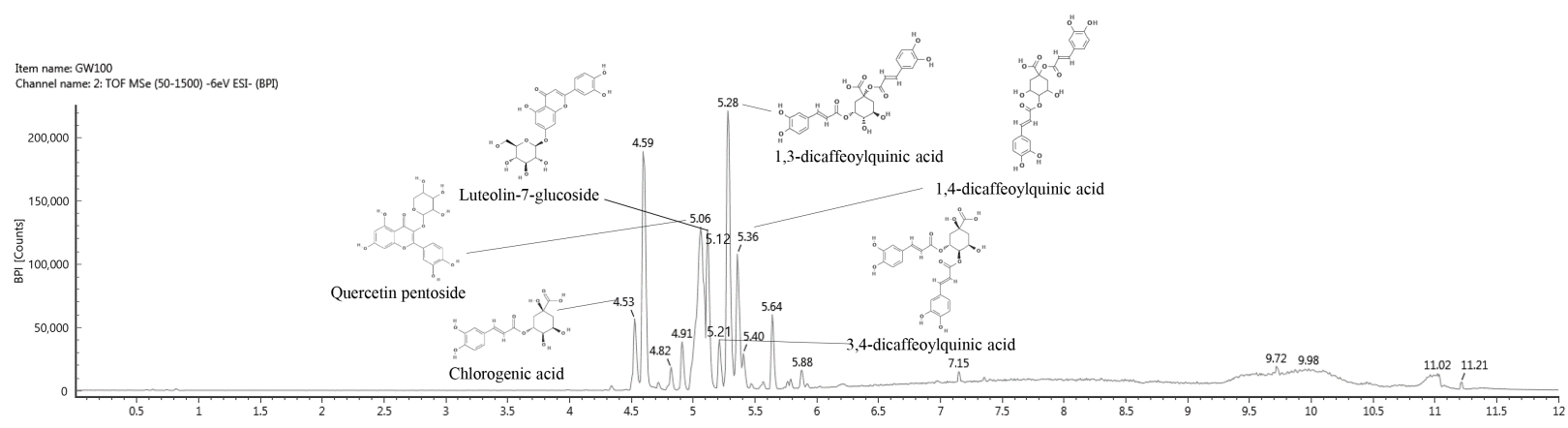

Fig. 1. UPLC Q-TOF/MS ${ }^{\mathrm{E}}$ chromatograph in negative ion mode of ethyl acetate fraction from Lonicera japonica (EFLJ). 
Table 2. Identification of main compounds of ethyl acetate fraction from Lonicera japonica

\begin{tabular}{|c|c|c|c|c|}
\hline No. & $\mathrm{RT}^{1)}(\min )$ & Parent ion ${ }^{2)}(\mathrm{m} / \mathrm{z})$ & $\mathrm{MS}^{\mathrm{E}}$ fragment $^{3)}(\mathrm{m} / \mathrm{z})$ & Compound \\
\hline 1 & 4.53 & 353.08 & 191.05 & Chlorogenic acid \\
\hline 2 & 5.06 & 433.13 & 300.03, 301.03 & Quercetin pentosiede \\
\hline 3 & 5.12 & 447.09 & 285.03 & Luteolin-7-glucoside \\
\hline 4 & 5.21 & 515.11 & 353.08, 173.04 & 3,4-Dicaffeoylquinic acid \\
\hline 5 & 5.28 & 515.12 & 353.08, 191.05 & 1,3-Dicaffeoylquinic acid \\
\hline 6 & 5.36 & 515.12 & 353.08, $191.05,173.04$ & 1,4-Dicaffeoylquinic acid \\
\hline
\end{tabular}

${ }^{1)} \mathrm{RT}$ means retention time.

${ }^{2)}$ Ions are presented at $\mathrm{m} / \mathrm{z}[\mathrm{M}-\mathrm{H}]^{-}$.

${ }^{3)}$ Bold indicates the main fragment of $\mathrm{MS}^{\mathrm{E}}$.

보호 효과가 있음을 입증 확인했다. 또한, 이러한 결과를 종합 하였을 때, 금은화의 chlorogenic acid, luteolin- 7-glucoside 그리고 dicaffeoylquinic acid 유도체 등의 페놀 화합물들은 산화적 스트레스로 인한 뇌 신경세포 보호와 기능 유지에 도 움을 줄 수 있는 천연 소재로써 활용할 수 있는 가능성을 가 지는 것으로 판단된다.

\section{ABTS 및 DPPH 라디칼 소거활성}

$\mathrm{ABTS}$ 라디칼 소거활성은 $\mathrm{ABTS}$ 시약의 potassium persulfate에 의해 인위적으로 생성된 양이온 라디칼이 시료 가 가지는 항산화 물질에 의해 제거되어 $\mathrm{ABTS}$ 라디칼의 색 인 청록색에서 무색으로 변하는 색 변화 정도를 측정하는 방 법으로, 수용성과 지용성 두 가지 물질의 항산화 능력을 측정 할 수 있어 범용으로 활용되는 방법이다(Re 등, 1999). ABTS

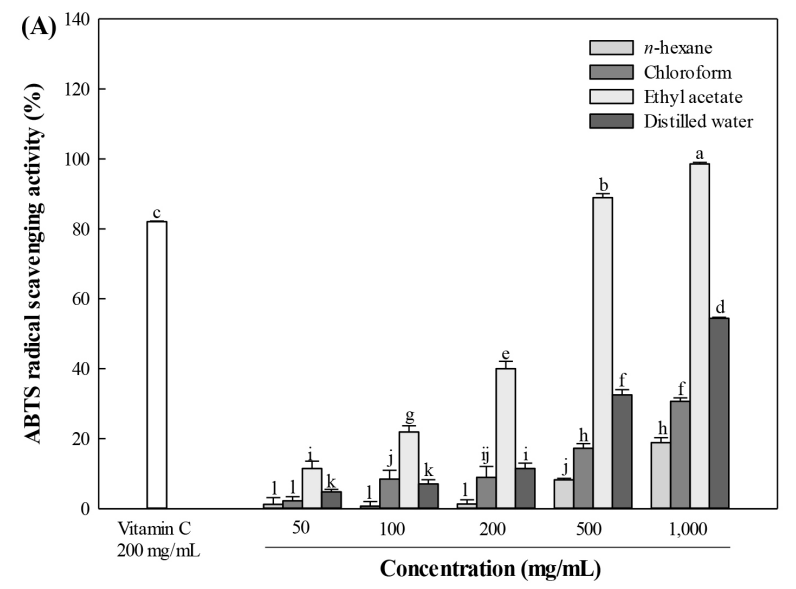

라디칼 소거 활성을 측정한 결과는 Fig. 2(A)와 같다. 1,000 $\mu \mathrm{g} / \mathrm{mL}$ 농도에서 ethyl acetate 분획물 $\left(98.56 \%, \mathrm{IC}_{50}=261.37\right.$ $\mu \mathrm{g} / \mathrm{mL})$ 이 증류수 분획물 $\left(54.40 \%, \mathrm{IC}_{50}=439.79 \mu \mathrm{g} / \mathrm{mL}\right)$ 에 비 해 약 1.8 배 높은 $\mathrm{ABTS}$ 라디칼 소거활성을 보였다. $\mathrm{DPPH}$ 라디칼 소거활성을 측정한 결과는 Fig. 2(B)와 같다. 1,000 $\mu \mathrm{g} / \mathrm{mL}$ 농도에서 ethyl acetate 분획물이 $90.80 \%$, 증류수 분 획물이 $34.66 \%$ 로 ethyl acetate 분획물의 DPPH 라디칼 소거 능이 증류수 분획물 대비 약 2.6 배 높은 것을 확인할 수 있었 다. Ethyl acetate 분획물의 $\mathrm{IC}_{50}$ 값은 $421.96 \mu \mathrm{g} / \mathrm{mL}$ 로 다른 분획물과 비교하였을 때 가장 낮은 값을 보여 우수한 라디칼 소거활성을 나타냈다. Cho 등(2013)의 연구에 따르면, 금은화 의 메탄올 추출에 의한 극성별 분획물 $(n$-hexane, chloroform, ethyl acetate, $n-\mathrm{BuOH}$, 증류수)의 항산화 활성을 $\mathrm{DPPH}$ 라디 칼 소거효과로 측정한 결과, $100 \mu \mathrm{g} / \mathrm{mL}$ 농도의 $\mathrm{BHA}$ 와 금은

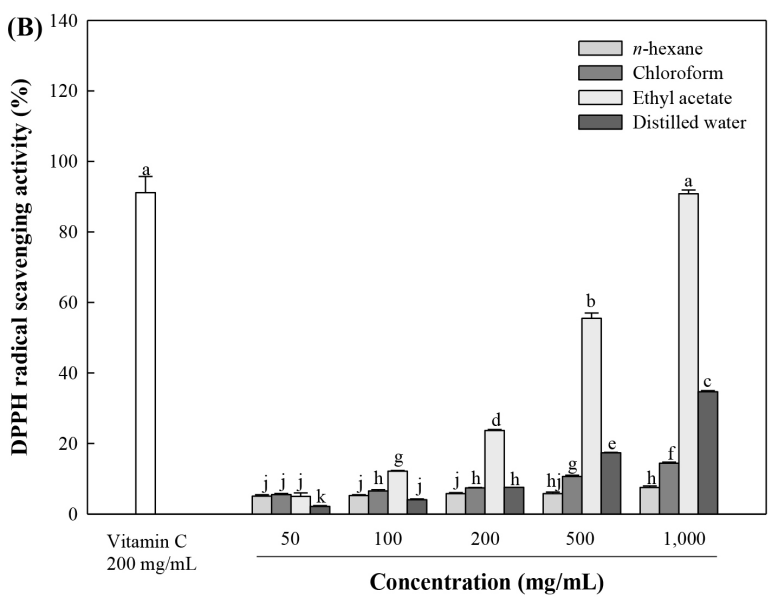

Fig. 2. ABTS radical scavenging activity (A) and DPPH radical scavenging activity (B) of $\boldsymbol{n}$-hexane, chloroform, ethyl acetate and distilled water fraction from Lonicera japonica.

Values are mean $\pm S D(n=3)$. Different small letters represent significant differences at $p<0.05$. 
화 추출 ethyl acetate 분획의 비교에서 이들은 유사한 라디칼 소거활성을 나타냈다. 또한, 금은화의 메탄올 추출물을 분획 하여 chloroform, ethyl acetate, $n-\mathrm{BuOH}$ 및 증류수 분획물로 $\mathrm{DPPH}$ 라디칼 소거효과를 측정한 결과, ethyl acetate 분획물 이 가장 $\mathrm{IC}_{50}$ 이 낮은 것을 확인했으며, 이는 ethyl acetate 분 획물이 상대적으로 다른 분획물보다 더 많은 luteolin, caffeic acid 및 protocatechuic acid 등의 활성 물질을 함유하기 때문 으로 판단된다(Choi 등, 2007). 따라서, 분획물 중 가장 in vitro 항산화 활성이 높은 금은화 ethyl acetate 분획물(ethyl acetate fraction of $L$. japonica, EFLJ)을 사용하여 이후 실험 을 진행하였다.

\section{철 환원력}

$\mathrm{FRAP}$ 을 통한 환원력 측정 실험은 산성의 조건에서 ferric tripyridyltriazine( $\mathrm{Fe}^{3+}$-TPTZ) 복합체가 ferrous tripyridyltriazine $\left(\mathrm{Fe}^{2+}-\mathrm{TPTZ}\right)$ 으로 환원이 되며, 높은 환원력을 가지는 시료에 의해 환원되는 양이 증가해 흡광도 값이 측정되는 것을 이용 하여 항산화 활성을 측정할 수 있다(Benzie과 Strain, 1996). 금은화의 ethyl acetate 분획물의 FRAP 분석에 의한 철 환원 력 측정 결과는 Fig. 3(A)에 나타냈다. 분획물의 농도가 증가 함에 따라 활성이 증가하는 경향을 보였으며, $500 \mu \mathrm{g} / \mathrm{mL}$ 와 $1,000 \mu \mathrm{g} / \mathrm{mL}$ 농도에서는 1.18 과 2.00 의 흡광도 값을 각각 나 타냈다. Lee 등(2019)의 연구에 따르면 reverse phase highperformance liquid chromatography(RP-HPLC)를 통한 chlorogenic acid, quercetin 함량은 금은화의 항산화 특성에 큰 영향을 미 치는 주요 활성 화합물로 보고하였으며, $\mathrm{Wu}(2007)$ 에 따르면 금은화의 chlorogenic acid는 $\mathrm{Fe}^{3+}$ 이온을 효과적으로 감소시

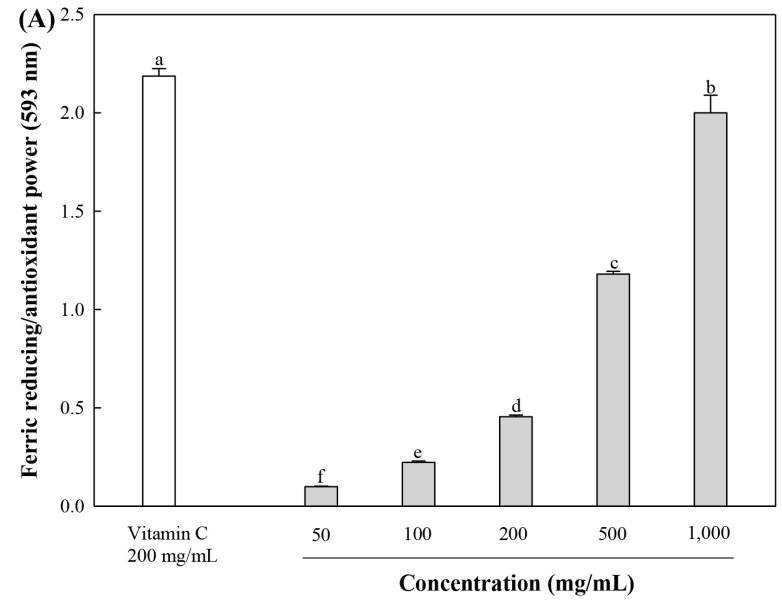

킬 수 있다고 보고했다. Miao 등(2018)에 따르면, 14종의 다 양한 화합물의 FRAP 환원력 측정 실험에서 chlorogenic acid 와 quercetin은 높은 철 환원력을 보여주었다. Firuzi 등(2005) 에 따르면, FRAP 분석에서 서로 다른 화합물(flavones, flavonols 및 isoflavones)의 시간에 따른 흡광도 변화를 확인 한 결과, quercetin이 효과적으로 $\mathrm{Fe}^{3+}$ 를 $\mathrm{Fe}^{2+}$ 로 환원시킨다고 보고했다. 따라서, chlorogenic acid와 quercetin과 같은 생리 활성 물질들이 금은화의 철 환원력 측정에 영향을 미치는 주 요 활성 화합물로 추정된다.

\section{지질과산화물 생성 억제활성}

뇌 조직은 세포막에 다가 불포화 지방산이 고농도로 존재 하고, 라디칼 형성 시 촉매로 이용되는 금속이온 $\left(\mathrm{Fe}^{2+}, \mathrm{Cu}^{2+}\right)$ 이 존재하기 때문에 산소의 요구량이 많아 쉽게 산화된다 (Kim 등, 2017). 금속이온은 펜톤반응을 통해서 ROS를 생성 과정에 관여하며, 과량의 ROS는 뇌의 불포화 지방산과 반응 하여, 지질 과산화 물질인 malondialdehyde(MDA)를 생성한 다(Reiter, 1995; Sung 등, 2000). 그 과정에서 세포 내에 많 은 MDA가 축적되면 세포막에서 교차결합, 중합 및 변성이 일어나 이온 수송, 효소 활성 및 세포 표면의 부착상태를 변 성시키며, $\mathrm{DNA}$ 의 염기와 반응하여 돌연변이성 병변을 일으 킨다고 알려져 있으며, 세포의 산화 스트레스의 지표로 사용 이 된다(Ji 등, 2013; Sung 등, 2000). 본 연구에서는 지질과 산화물 함량을 측정함으로써 EFLJ의 지질과산화 생성 억제 효과를 평가했다(Fig. 3(B)). EFLJ의 $50 \mu \mathrm{g} / \mathrm{mL}$ 농도에서 $70.88 \%$ 를, 양성대조군인 카테킨은 동일 농도에서 $71.03 \%$ 를 나타냈지만, $\mathrm{EFLJ}$ 의 $\mathrm{IC}_{50}$ 은 $21.24 \mu \mathrm{g} / \mathrm{mL}$ 로, 양성대조군인

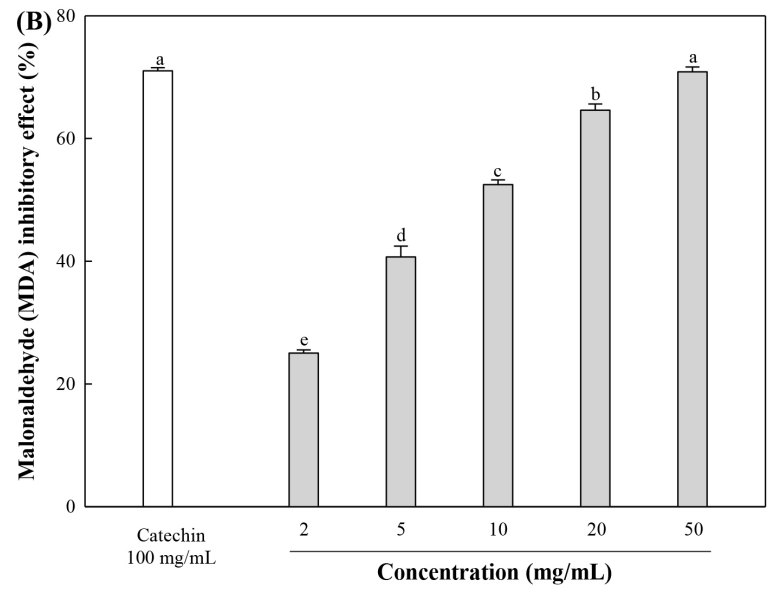

Fig. 3. Ferric reducing/antioxidant power (FRAP) (A) and inhibitory effect of malondialdehyde (MDA) (B) of ethyl acetate fraction from Lonicera japonica (EFLJ).

Values are mean $\pm \mathrm{SD}(\mathrm{n}=3)$. Different small letters represent significant differences at $\mathrm{p}<0.05$. 
카테킨 $(23.03 \mu \mathrm{g} / \mathrm{mL})$ 과 비교하였을 때, 낮은 $\mathrm{IC}_{50}$ 값을 나타 내 우수한 지질과산화물 생성 억제 활성을 갖는 것을 확인했 다. Yi 등(2011)의 연구에서, lipopolysaccharide(LPS)로 유발 된 급성 폐 손상에 금은화 물 추출물이 미치는 영향을 알아밨 을 때, LPS 투여 시 폐 내의 MDA 함량의 증가가 되었으나, 금은화 물 추출물 투여를 통해 폐 내 MDA 함량의 증가가 억제됨을 확인했다. 또한, rats에서 dimethylnitrosamine으로 유도된 급성 간 손상에 대한 $\mathrm{MDA}$ 함량이 감소하였다(Teng 등, 2010). 금은화의 주된 성분인 chlorogenic acid는 rat의 뇌 에서 sodium nitroprusside, quinolinic 및 $\mathrm{Fe}^{2+}$ 에 의해 각각 유 도된 산화 스트레스에 대한 MDA 생산을 억제하였다(Oboh 등, 2013). 이러한 연구와 유사하게 본 연구에서도 EFLJ는 $\mathrm{MDA}$ 수준을 억제할 수 있을 것으로 판단된다.

\section{아세틸콜린 분해효소 억제활성}

체내의 대표적인 신경전달 물질 중 하나인 아세틸콜린 (acetylcholine, ACh)은 콜린성 신경계에 주로 분포하는 기억 메커니즘의 핵심 요소 중 하나이다(Watanabe 등, 2009). 아세 틸콜린은 choline acetyltransferase 효소의 작용을 받아 acetyl $\mathrm{CoA}$ 와 choline이 합성되고, 이는 다시 $\mathrm{AChE}$ 효소의 작용으 로 acetate와 choline으로 분해된다. 하지만, $\mathrm{AChE}$ 의 농도가 증가하면 뇌 신경세포의 콜린성 신경전달물질이 분해되어 기 억 및 인지기능 장애가 유발될 수 있다(Vincenzo, 2001). 따 라서 본 연구에서는 금은화의 $\mathrm{AChE}$ 의 억제 활성을 확인했 다(Fig. 4). EFLJ의 $\mathrm{IC}_{50}$ 은 $282.72 \mu \mathrm{g} / \mathrm{mL}$ 로 나타났으며, 양성 대조군인 tacrine의 $\mathrm{IC}_{50}$ 은 $49.3 \mathrm{ng} / \mathrm{mL}$ 로 나타났다. 금은화 주성분인 chlorogenic acid는 유의적으로 $\mathrm{AChE}$ 활성을 억제

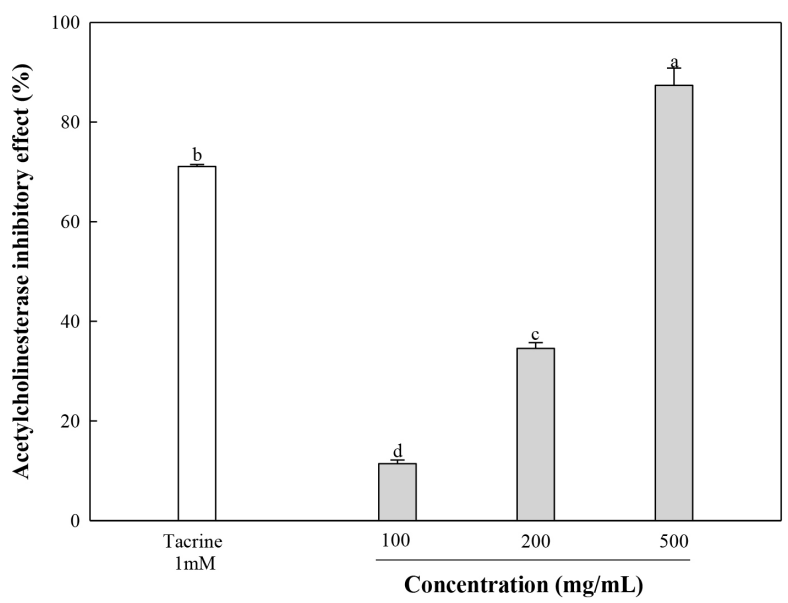

Fig. 4. Acetylcholinesterase (AChE) inhibitory effect of ethyl acetate fraction from Lonicera japonica (EFLJ).

Values are mean $\pm \mathrm{SD}(\mathrm{n}=3)$. Different small letters represent significant differences at $\mathrm{p}<0.05$.
했으며(Oboh 등, 2013), Yoo 등(2013)의 연구에 따르면 scopolamine에 의해 기억 상실이 유도된 쥐 모델에서 luteolin 이 이랑(dentate gyrus)에서 $\mathrm{AChE}$ 수준을 감소시켜줌으로써 인지기능의 개선을 나타냈다. 이러한 결과를 바탕으로 luteolin 과 chlorogenic acid 등과 같은 폴리페놀 화합물에 의한 $\mathrm{AChE}$ 억제 활성이 유도된 것으로 판단되며, 이러한 생리활 성 물질을 통해서 아세틸콜린 분해를 효과적으로 저해하는 데 도움이 될 것으로 판단된다.

\section{뇌 신경세포 생존율 측정 및 산화적 스트레스 생성 억제효과}

세포 내 ROS는 반응성이 매우 높은 화합물로 지질, 단백 질 및 $\mathrm{DNA}$ 를 산화시켜 세포의 손상이나 게놈 불안정을 유발 하는 산화적 스트레스를 발생시킨다(Dizdaroglu 등, 2012). 산화 스트레스는 주로 활성 산소 종 (ROS), 활성 질소 종 (reactive nitrogen species, RNS) 및 항산화 방어 메커니즘으 로 구성된 상대적으로 높은 수준의 독성 반응성 종의 존재 사 이에서 불균형을 특징으로 하는 생화학적 상태이다(Ozben, 2007). 산화적 스트레스는 신경세포 핵과 미토콘드리아 DNA 의 손상을 증가시키며, 항산화 효소의 활성을 감소시키고, 산 화적 스트레스를 일으키는 ROS는 신경 손상을 일으켜 알츠 하이머성 질환(Alzheimer's disease, $\mathrm{AD}$ )과 같은 퇴행성 뇌 신경 질환과 기억력 장애를 유발한다(Heo 등, 2004). 식물 유 래 플라보노이드 및 폴리페놀 화합물은 이러한 산화적 스트 레스에 대한 보호 효능이 우수한 것으로 알려져 있어 천연 유래 소재의 연구가 필요하다(Ishige 등, 2001). 본 연구에서 는 과산화수소로 유도된 HT22와 MC-IXC 세포에서 금은화 ethyl acetate 분획물의 산화적 스트레스에 대한 보호 효과를 확인하였다. 항산화 실험에서, 비타민 $\mathrm{C}$ 와 비교하기 위해 유 사한 금은화 샘플의 농도를 설정하였으며, 활성이 우수한 금 은화 ethyl acetate 분획물의 $\mathrm{IC}_{50}$ 을 구하고자 $50 \mu \mathrm{g} / \mathrm{mL}$ $1,000 \mu \mathrm{g} / \mathrm{mL}$ 농도를 설정했다. 세포 실험의 경우, 사전 실험 을 통해 세포에 독성을 일으키지 않는 최적의 농도를 확인했 으며, $5 \mu \mathrm{g} / \mathrm{mL}-50 \mu \mathrm{g} / \mathrm{mL}$ 로 하여 세포실험을 진행했다.

MTT 분석은 살아있는 세포 속 미토콘드리아가 MTT 시 약과 함께 배양되었을 때, 포르마잔(formazan) 결정을 생성 하는 것을 이용한 세포 생존율 측정 방법이다(Heo 등, 2001). 과산화수소로 인한 산화적 스트레스가 유도된 HT22와 MC$\mathrm{IXC}$ 뇌 신경세포 생존율을 측정한 결과는 다음과 같다(Fig. 5). HT22 세포에서 신경세포 생존율을 측정한 결과, 과산화 수소를 처리한 HT22 신경세포에서는 대조군 대비 $61.39 \%$ 의 신경세포 생존율을 나타냈지만, 양성대조군인 비타민 $\mathrm{C}$ 는 $75.00 \%$ 의 신경세포 생존율 상승을 보였다(Fig. 5(A)). Ethyl acetate 분획물 $20 \mu \mathrm{g} / \mathrm{mL}$ 와 $50 \mu \mathrm{g} / \mathrm{mL}$ 농도의 EFLJ는 각각 $74.54 \%, 102.06 \%$ 의 신경세포 생존율을 나타냈다. MC-IXC 

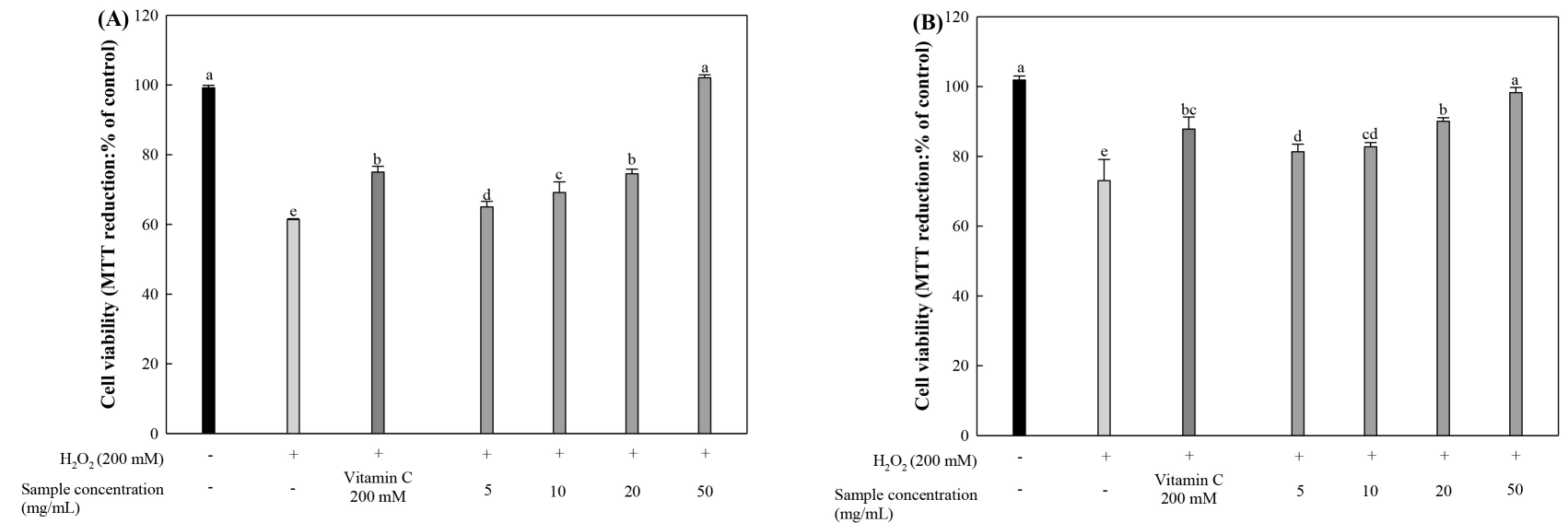

Fig. 5. Neuronal cell viability of ethyl acetate fraction from Lonicera japonica (EFLJ) on $\mathrm{H}_{2} \mathrm{O}_{2}$-induced cytotoxicity in $\mathrm{HT} 22$ cells (A) and MC-IXC cells (B).

Values are mean $\pm \mathrm{SD}(\mathrm{n}=3)$. Different small letters represent significant differences $(\mathrm{p}<0.05)$.

신경세포에서의 신경세포 생존율을 측정한 결과, 과산화수소 를 처리한 MC-IXC 신경세포에서는 대조군 대비 $73.02 \%$ 의 신 경세포 생존율을 보였으며, 양성대조군인 비타민 C는 $87.81 \%$ 의 신경세포 생존율을 보였다(Fig. 5(B)). EFLJ $20 \mu \mathrm{g} / \mathrm{mL}$ 와 $50 \mu \mathrm{g} / \mathrm{mL}$ 농도는 각각 $90.03 \%, 98.24 \%$ 를 나타냈다. HT22 와 MC-IXC 두 세포에서 모두 $20 \mu \mathrm{g} / \mathrm{mL}$ 에서는 양성대조군인 비타민 C와 유사한 신경세포 생존율을 나타냈으며, $50 \mu \mathrm{g} / \mathrm{mL}$ 에서는 뇌신경세포 생존율이 비타민 $\mathrm{C}$ 보다 더 높은 신경세포 생존율을 나타냈다.

뇌 신경세포 내 활성산소종의 함량 측정 방법인 DCF-DA 실험은 세포 내 미토콘드리아에서 비형광 화합물인 DCF-DA

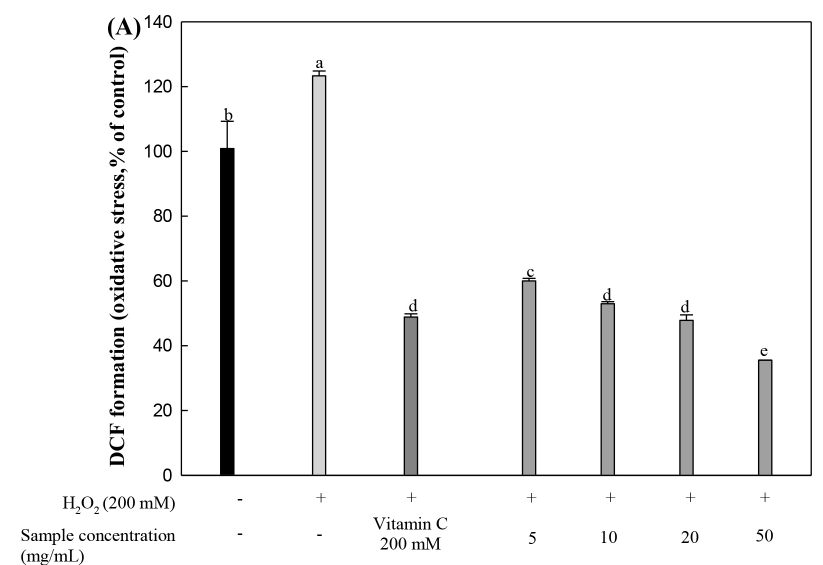

가 세포 내에서 $\mathrm{ROS}$ 존재 시에 산화되어 형광을 띄는 $\mathrm{DCF}$ 로 분해된다(Heo 등, 2001). 과산화수소로 인한 산화적 스트 레스가 유도된 HT22와 MC-IXC 세포에서의 활성산소종 생 성 정도를 측정한 결과는 다음과 같다(Fig. 6). 과산화수소를 처리한 HT22 세포에서 대조군 대비 $123.30 \%$ 의 ROS 함량을 보였고, 양성대조군인 비타민 C는 대조군 대비 $59.99 \%$ 의 ROS 함량을 나타냈다(Fig. 6(A)). EFLJ 20과 $50 \mu \mathrm{g} / \mathrm{mL}$ 농 도는 각각 $47.85 \%, 35.54 \%$ 의 형광 광도를 보였으며, 양성대 조군인 비타민 $\mathrm{C}$ 와 비교했을 때, 효과적으로 세포 내 활성산 소종의 생성이 감소된 것을 확인할 수 있었다. MC-IXC 세포 에서는 과산화수소를 처리한 그룹에서 대조군 대비 $112.77 \%$

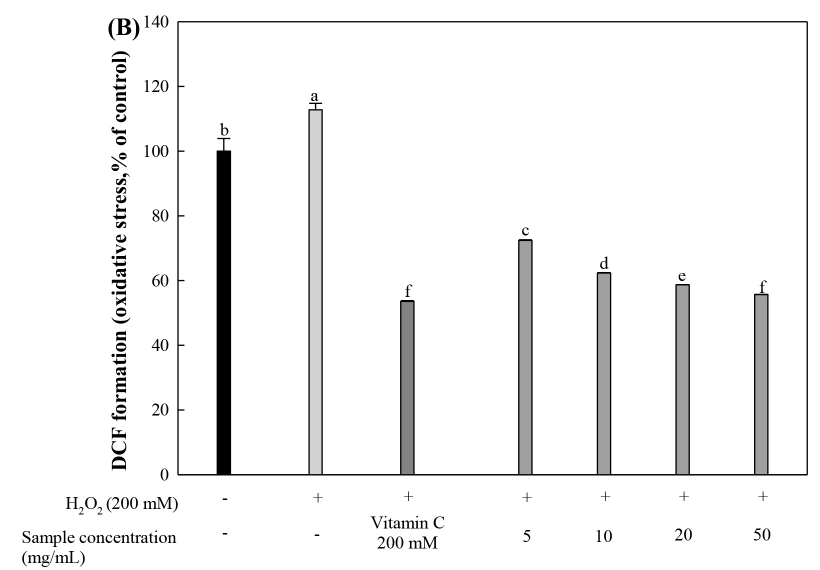

Fig. 6. ROS production of ethyl acetate fraction from Lonicera japonica (EFLJ) on $\mathrm{H}_{2} \mathrm{O}_{2}$-induced cytotoxicity in $\mathrm{HT22}$ cells (A) and MC-IXC cells (B).

Values are mean $\pm \mathrm{SD}(\mathrm{n}=3)$. Different small letters represent significant differences at $\mathrm{p}<0.05$. 
의 형광 광도가 증가하는 것을 확인했고, 과산화수소와 비타민 $\mathrm{C}$ 를 동시에 처리한 집단에서는 $53.54 \%$ 의 형광 광도를 나타냈 다(Fig. 6(B)). EFLJ $20 \mu \mathrm{g} / \mathrm{mL}$ 와 $50 \mu \mathrm{g} / \mathrm{mL}$ 농도로 MC-IXC 세포에 처리하였을 때, 각각 $58.69 \%$ 와 $55.68 \%$ 의 형광 광도 를 보였으며, 양성대조군인 비타민 C와 비교해 보았을 때, 유 사한 활성산소종의 생성 억제를 나타냈다.

이는 높은 항산화 활성을 가진 금은화가 생리적 특성상 높 은 산소 농도가 요구되는 반면, 높은 수준의 불포화 지방산을 가지는 뇌 조직에서, 생체 세포막의 주요 구성성분인 다중 불 포화 지방산을 $\mathrm{MDA}$ 로 전환하는데 주된 관여를 하는 $\mathrm{ROS}$ 를 제거함으로써 뇌 신경세포 보호 효과를 나타내는 것으로 판 단된다(Choi 등, 2012). 대뇌 신경세포인 rat C6 glioma cell 에서는, $\mathrm{AlCl}_{3}$ 가 신경전달 물질에 손상을 주어 신경연접 (synapse)간 원활한 자극전달을 방해하거나 자유라디칼의 생 성 유발로 인해 감소된 신경세포 생존율을 금은화 추출물이 유의하게 증가시킴으로써 세포독성을 억제했다고 보고된 바 있다(Jung 등, 2017). Peng 등(2005)에 따르면, 금은화는 hyperoside, chlorogenic acid, luteolin 및 caffeic acid를 주요 생리활성 성분으로 가지고 있음을 확인했으며, Son 등(2020) 의 연구에 따르면, 금은화 생리활성물질 중 하나인 caffeic acid가 glutamate로 인해 신경독성이 유도된 HT22 세포에서 신경세포 보호활성을 가지며, ROS로 인한 세포 사멸을 막아 주는 것을 확인할 수 있었다. 이런 결과를 종합해 볼 때, 금은 화의 caffeic acid 물질뿐만이 아니라, 금은화의 다양한 생리 활성 물질들이 뇌 신경세포 생존율의 증가와 활성산소종의 생성을 억제함으로써 신경세포 보호 효과를 갖는 천연 항산 화제로서의 활용 가능성이 있는 것으로 판단된다.

\section{요 약}

금은화의 ethyl acetate 분획물을 이용하여 in vitro 항산화 활성을 평가하였고, $\mathrm{H}_{2} \mathrm{O}_{2}$ 로 유도된 산화적 스트레스에 대한 뇌 신경세포 보호 효과를 확인하였다. 에탄올 농도에 따른 금 은화 총페놀성 화합물 및 총플라보노이드 함량 측정 결과, $40 \%$ 에탄올 추출물에서 가장 높게 나타났다. 가장 우수한 함 량을 보인 $40 \%$ 에탄올 추출물로부터 분리된 분획물의 $\mathrm{ABTS}$, $\mathrm{DPPH}$ 라디칼 소거활성 측정한 결과, ethyl acetate 분획물 (EFLJ)의 라디칼 소거활성이 가장 높음을 확인했다. EFLJ의 철 환원력(FRAP)과 지질과산화물(MDA) 생성 억제 활성 측 정을 통해 $\mathrm{EFLJ}$ 의 항산화력을 확인하였으며, $\mathrm{AChE}$ 억제 활 성을 확인하였다. 또한, 금은화는 과산화수소로 인해 유도된 산화적 독성으로부터 뇌 신경세포 생존율의 증가와 활성산소 종 감소를 통해 우수한 뇌 신경세포 보호 효과를 나타냈다. 본 연구를 바탕으로 금은화 ethyl acetate 분획물은 우수한 항
산화효과와 이를 바탕으로 산화적 스트레스에 대한 뇌 신경 세포 보호 효과를 가지는 것으로 판단된다. 따라서, 국내산 금은화는 향후 in vivo 및 ex vivo 실험을 통해 퇴행성 뇌신경 계질환의 예방 또는 치료제로 개발될 수 있는 건강기능식품 소재로서의 구체적인 가능성을 부여할 수 있을 것이다.

\section{감사의 글}

본 연구는 정부의 재원으로 한국연구재단의 개인기초연구 (2018RIDIA3B07043398)의 지원을 받아 수행된 결과로 이 에 감사드립니다.

\section{Conflict of interests}

The authors declare no potential conflict of interest.

\section{ORCID}

Hye Rin Jeong https://orcid.org/0000-0003-2192-6470 Ho Jin Heo https://orcid.org/0000-0002-3560-2007

\section{References}

Bae JH, Kim MS, Kang EH. Antimicrobial effect of Lonicerae flos extracts on food-borne pathogens. Kor J Food Sci Technol, 37, 642-647 (2005)

Behl C, Moosmann B. Oxidative nerve cell death in Alzheimer's disease and stroke: Antioxidants as neuroprotective compounds. Biol Chem, 383, 521-536 (2002)

Benzie IFF, Strain JJ. The ferric reducing ability of plasma (FRAP) as a measure of "antioxidant power": The FRAP assay. Anal Biochem, 239, $70-76$ (1996)

Blois MS. Antioxidant determinations by the use of a stable free radical. Nature, 181, 1199-1200 (1958)

Chang ST, Wu JH, Wang SY, Kang PL, Yang NS, Shyur LF. Antioxidant activity of extracts from Acacia confusa Bark and heartwood. J Agric Food Chem, 49, 3420-3424 (2001)

Cho WJ, Yoon HS, Kim YH, Kim JM, Yoo IJ, Han MD, Bang IS. Cytoprotective effects and gene expression patterns observed based on the antioxidant activity of Lonicera japonica extract. J Life Sci, 23, 989-997 (2013) 
Cho YJ, Ju IS, Kwon OJ, Chun SS, An BJ, Kim JH, Biological and antimicrobial activity of Portulaca oleracea. J Korean Soc Appl Biol Chem, 51, 49-54 (2008)

Choi CW, Jung HA, Kang SS, Choi JS. Antioxidant constituents and a new triterpenoid glycoside from Flos lonicerae. Arch Pharm Res, 30, 1-7 (2007)

Choi MJ, Kim HK, Lee MS. Vitamin E in vivo studies on the activity of antioxidant enzymes and CYP2E1 expression in high PUFA-treated brains. J Korean Soc Food Sci Nutr, 41, 1106-1111 (2012)

Dizdaroglu M, Jaruga P. Mechanisms of free radical-induced damage to DNA. Free Radic Res, 46, 382-419 (2012)

Ellman GL, Courtney KD, Andres Jr V, Featherstone RM. A new and rapid colorimetric determination of acetylcholinesterase activity. Biochem Pharmacol, 7, 88-90 (1961)

Firuzi O, Lacanna A, Petrucci R, Marrosu G, Saso L. Evaluation of the antioxidant activity of flavonoids by "ferric reducing antioxidant power" assay and cyclic voltammetry. Biochim Biophys Acta, 1721, 174-184 (2005)

Heo HJ, Cho HY, Hong B, Kim HK, Kim EK, Kim BG, Shin DH. Protective effect of 4',5-dihydroxy-3',6,7trimethoxyflavone from Artemisia asiatica against $\mathrm{A} \beta$ -induced oxidative stress in PC12 cells. Amyloid, 8, 194-201 (2001)

Heo HJ, Kim DO, Choi SJ, Shin DH, Lee CY. Potent inhibitory effect of flavonoids in Scutellaria baicalensis on amyloid beta protein-induced neurotoxicity. J Agric Food Chem, 52, 4128-4132 (2004)

Herrmann $\mathrm{K}$. On the occurrence of flavonol and flavone glycosides in vegetables. Z Lebensm Unters Forsch, 186, $1-5$ (1988)

Herto MG, Hollman PC, Van de Putte B. Content of potentially anticarcinogenic flavonoids of tea infusions, wines, and fruit juices. J Agric Food Chem, 41, 1242-1246 (1993)

Hvattum E. Determination of phenolic compounds in rose hip (Rosa canina) using liquid chromatography coupled to electrospray ionisation tandem mass spectrometry and diode-array detection. Rapid Commun Mass Spectrom, 16, 655-662 (2002)

Ishige K, Schubert D, Sagara Y. Flavonoids protect neuronal cells from oxidative stress by three distinct mechanisms. Free Radic Biol Med, 30, 433-446 (2001)

Ji N, Song JL, Kil JH, Park KY. Protective effects of Perilla frutescens Britt var. japonica extracts from oxidative stress in human HaCaT keratinocytes. J Korean Soc Food Sci Nutr, 42, 161-167 (2013)

Jung JY, Jung IJ, Jekal SJ. The protective effect of Lonicerae flos extract on cultured C6 glioma cells damaged by aluminum of dementia inducer. Korean $\mathrm{J}$ Clin Lab Sci, 49, 271-278 (2017)

Kim DO, Jeong SW, Lee CY. Antioxidant capacity of phenolic phytochemicals from various cultivars of plums. Food Chem, 81, 321-326 (2003)

Kim HY, Woo KS, Hwang IG, Lee YR, Jeong HS. Effects of heat treatments on the antioxidant activities of fruits and vegetables. Korean J Food Sci Technol, 40, 166-170 (2008)

Kim KB, Lee SA, Heo JH, Kim JH. Neuroprotective effects of Momordica charantia extract against hydrogen peroxide-induced cytotoxicity in human neuroblastoma SK-N-MC cells. J Nutr Health, 50, 415-425 (2017)

Kim SS, Park RY, Jeon HJ, Kwon YS, Chun W. Neuroprotective effects of 3, 5-dicaffeoylquinic acid on hydrogen peroxide-induced cell death in SH-SY5Y cells. Phytother Res, 19, 243-245 (2005)

Kim Y, Yang SY, Oh YS, Lee JW, Lee YK, Park YC. Research trends of Lonicera japonica over the last 10 year. J Daejeon Oriental Med, 19, 17-23 (2010)

Kwon SH, Lee HK, Kim JA, Hong SI, Kim HC, Jo TH, Park YI, Lee CK, Kim YB, Lee SY, Jang CG. Neuroprotective effects of chlorogenic acid on scopolamine-induced amnesia via anti-acetylcholinesterase and anti-oxidative activities in mice. Eur $\mathrm{J}$ Pharmacol, 649, 210-217 (2010)

Lee J, Park G, Chang YH. Nutraceuticals and antioxidant properties of Lonicera japonica Thunb. as affected by heating time. Int J Food Prop, 22, 630-645 (2019)

Lee DH, Kim ML. Relationship between self-efficacy and health promotion behavior according to university students' participation in sports activity. J Korean Phys Soc, 19, 459-468 (2017)

Lim SJ, Kim YS. Suppressed synthesis of reactive oxygen species from HL60 cell by nicotine. Cancer Prev Res, 12, 35-39 (2007) 
Lima CF, Fernandes-Ferreira M, Pereira-Wilson C. Phenolic compounds protect HepG2 cells from oxidative damage: Relevance of glutaethion levels. Life Sci, 79, 2056-2068 (2006)

Miao J, Li X, Zhao C, Gao X, Wang Y, Gao W. Active compounds, antioxidant activity and $\alpha$-glucosidase inhibitory activity of different varieties of Chaenomeles fruits. Food Chem, 248, 330-339 (2018)

Niki E, Noguchi N, Gotoh N. Dynamics of lipid peroxidation and its inhibition by antioxidants. Biochem Soc Trans, 21, 313-317 (1993)

Oboh G, Agunloye OM, Akinyemi AJ, Ademiluyi AO, Adefegha SA. Comparative study on the inhibitory effect of caffeic and chlorogenic acids on key enzymes linked to Alzheimer's disease and some pro-oxidant induced oxidative stress in rats' brain-in vitro. Neurochem Res, 38, 413-419 (2013)

Ozben T. Oxidative stress and apoptosis: impact on cancer therapy. J Pharm Sci, 96, 2181-2196 (2007)

Peng Y, Liu F, Ye J. Determination of phenolic acids and flavones in Lonicera japonica Thumb. by capillary electrophoresis with electrochemical detection. Electroanalysis, 17, 356-362 (2005)

Pham-Huy LA, He H, Pham-Huy C. Free radicals, antioxidants in disease and health. Int J Biomed Sci, 4, 89-96 (2008)

Re R, Pellegrini N, Proteggente A, Pannala A, Yang M, Rice-Evans C. Antioxidant activity applying improved ABTS radical cation decolorization assay. Free Radic Bio Med, 26, 1231-1237 (1999)

Reiter RJ. Oxidative processes and antioxidative defense mechanisms in the aging brain. FASEB J, 9, 526-533 (1995)

Sen S, Chakraborty R, Sridhar C, Reddy Y, De B. Free radicals, antioxidants, diseases and phytomedicines: Current status and future prospect. Int J Pharm Sci Rev Res, 3, 91-100 (2010)

Shin JH, Yoo SK. Antioxidant properties in microbial fermentation products of Lonicera japonica Thunb. extract. J East Asian Soc Diet Life, 22, 95-102 (2012)

Son Y, Ma CJ, Neuroprotective activity of caffeic acid isolated from Lonicera japonica. Kor J Pharmacogn, 51,
30-35 (2020)

Song SY, Kim MK, Ha HY. Optimal extraction conditions of phenolic compounds, flavonoids and chlorogenic acid of Lonicera japonica Flos. J Adv Eng and Tech, 11, 1-5 (2018)

Sung KS, Chun C, Kwon YH, Kim KH, Chang CC. Effects of red ginseng component on the antioxidative enzymes activities and lipid peroxidation in the liver of mice. $\mathrm{J}$ Ginseng Res, 24, 29-34 (2000)

Teng Y, Sun CH, Li G, Sun G, Nomachi Y, Yokota J, Yoshioka S, Gang Jinbo, Jiao S, Zhang Y, Miyamura M. Protective effects of Flos lonicera extract on acute liver injury by dimethylnitrosamine-induced in rats. J Nat Med, 64, 288-294 (2010)

Vincenzo NT. Acetylcholinesterase in Alzheimer's disease. Mech Ageing Dev, 122, 1961-1969 (2001)

Watanabe T, Yamagata N, Takasaki K, Sano K, Hayakawa K, Katsurabayashi S, Egashira N, Mishima K, Iwasaki K, Fujiwara M. Decreased acetylcholine release is correlated to memory impairment in the $\mathrm{Tg} 2576$ transgenic mouse model of Alzheimer's disease. Brain Res, 1249, 222-228 (2009)

$\mathrm{Wu} \mathrm{L}$. Effect of chlorogenic acid on antioxidant activity of Flos lonicerae extracts. J Zhejiang Univ Sci B, 8, 673679 (2007)

Yi CG, Choi HY, Park MY, Kim JD. Effects of Lonicerae flos extracts on LPS-induced acute lung injury. Korean J Orient Prev Med, 15, 49-69 (2011)

Yoo DY, Choi JH, Kim W, Nam SM, Jung HY, Kim JH, Won MH, Yoon YS, Hwang IK. Effects of luteolin on spatial memory, cell proliferation, and neuroblast differentiation in the hippocampal dentate gyrus in a scopolamine-induced amnesia model. Neurol Res, 35, 813-820 (2013)

Yoon MY. A study on anti-oxidant activity and antiinflammatory action of sea buckthorn seed extract. Kor Soc Biotech J, 28, 327-331 (2013)

Yu PY, Kim HH, Lee YL, Park SY, Jung MY, Choi JH. Effects of hot water extracts from Lonicera japonica Flos extracts on whitening using B16F10 cell lines. J Korean Med Ophthalmol Otolaryngol Dermatol, 30, $38-50$ (2017) 